TRAMES, 2008, 12(62/57), 4, 400-420

\title{
RECONSIDERING THE FINNISH MODEL - INFORMATION SOCIETY POLICY AND MODES OF GOVERNANCE
}

\author{
Antti Pelkonen
}

\author{
University of Helsinki
}

\begin{abstract}
During the last two decades, Finland has experienced an extensive societal transformation in which the Nordic welfare state model has been challenged by economic turbulences and globalisation. At the same time, the building of an information society, in which there is a growing emphasis on economic competitiveness and knowledge-intensive production, has become a central political metaobjective and formed a new national strategy. This article examines governance changes related to these transformations. The analysis shows that the Finnish experience combines both strong corporatist and market modes of governance but, at the same time, there has been a significant increase in social inequality related to the growing market governance. Such inequalities have been mostly neglected in recent discussions of the Finnish 'model' or 'miracle'. The corporatist system shows a limited capacity towards deliberative and more inclusive approaches, but it also tends to merge with educational modes of governance.
\end{abstract}

DOI: $10.3176 /$ tr.2008.4.03

Keywords: equality, Finland, governance, information society, information and communication technologies, innovation policy, public engagement

\section{Introduction}

Finland has traditionally been considered as belonging to Nordic welfare states which have emphasized broad participation in working life, relatively low unemployment and extensive and redistributive welfare policy. The building of the welfare state in Finland can be seen as a broad project to modernize the society which has aimed at increasing societal and regional equality, balancing income differences and modernising industrial and economic structures (Cabinet programmes 1976-1983). Politically, the building of the welfare state centred around a center-left coalition with interest groups and in particular farmers having a strong position. Although the labour union has never had as powerful a position as in other Nordic countries, the building of the welfare state has favoured 
corporatist governance structures aiming at balancing conflicts between capital and labour and increasing consensual politics over time.

Yet, during the late 1980s and 1990s Finland experienced major changes. The country was still building up the welfare regime when it was hit by a banking crisis and a severe economic recession. While at the end of the 1980s the Finnish GDP had grown 5 per cent annually, in 1991 and 1992 the growth turned into a decrease of 7 and 4 per cent respectively. ${ }^{1}$ The rise of unemployment was remarkably fast: in 1992 unemployment rate in Finland was one of the smallest in Europe, but in 1993 it was 16.4 per cent, the highest in Europe after Spain (OECD 2005). Such transition from a country of almost full employment into a country with high unemployment is unique in the OECD countries after the Second World War (Kantola 2002). The recession added momentum to political changes, and in consequence, the closed planning economy was opened, the country joined European integration and market-oriented policies started to gain ground.

By the middle of the 1990s, however, the Finnish economy was already rapidly recovering and in particular the development of the Finnish information and communication technology (ICT) cluster started to receive international attention. The Finnish economy was suddenly taken as an example of how the production and use of ICTs can change the economic structure, increase productivity and promote economic wellbeing. International competitiveness rankings started to rank Finland in the top positions and the ICT-driven economic recovery was termed as the Finnish 'miracle' (e.g. Benner 2003). In consequence, the Finnish experience has been considered as a paradigmatic example of societal transformation in the information age. Several observers have started to point to a 'Finnish model' which has been considered as exceptional in that it is able to combine a highly competitive knowledge-intensive economy with an inclusive welfare model (Castells and Himanen 2002, Himanen and Castells 2004:43-51, see also Schienstock 2004, Saari 2006). In their influential account Manuel Castells and Pekka Himanen (2002), for instance, see that there is a virtuous circle between the informational economy and the welfare state: economic growth provides the possibilities for financing the welfare services and the welfare state produces educated people, skilled workforce and social protection which are the preconditions for further innovations and growth of the informational economy. In this way, Finland has been seen as an example of successful adaptation to globalisation in that it has been able to move into knowledge-intensive production "while not deviating from the established welfare and employment policies" (Benner 2003:147).

This picture, however, tends to neglect several important aspects of the Finnish experience. In particular, it does not take into account the weakening of the social dimension and increasing social inequalities (c.f. Heiskala 2006). It would thus be relevant to ask whether the building of an information society in which competitive-

The downswing of the economy was particularly severe: in similar economic crisis in industrialized countries the decrease of GDP has often been 2 per cent (Kantola 2002). 
ness of the economy, the promotion of new technologies - in particular new information and communication technologies - and enhancement of knowledgeintensive production structures are increasingly central, has actually surpassed the welfare state project (see also Pelkonen 2008). ${ }^{2}$ This article, therefore, aims to take a more critical approach towards the Finnish experience and to analyse the modes of governance related to the development of the information society in Finland. Governance, in this respect, is understood in broad terms as the changing relationship between the state and society and how the state interacts with its environment, how it 'governs' or 'manages' the society and economy (Pierre and Peters 2000). ${ }^{3}$ The specific focus here is on the role that is assigned to the public in policy-making and how citizens are involved in decision-making processes.

While information and communication technologies have been a major factor in the societal transformation in Finland during the last decade, the role of ICTs is increasingly emphasized in recent societal strategies. Emphasis is particularly put on the need to increase the application of ICTs in all societal spheres and thus improve productivity (e.g. Information Society Council 2006). Latest visions use the term "ubiquitous information society" to refer to a society in which information and communication technologies and wireless communication and networking are pervasive (Huovinen 2006). Through 'intelligent' homes and devices information and communication technologies are increasingly expected to penetrate peoples' everyday lives. At the same time there are increasing risks and uncertainties related to the growing application of ICTs, such as mobile phone health risks, privacy and safety in mobile communication and growing digital divide. There is, therefore, a growing need to take the perspective of citizens and users seriously and integrate the aspect of governance to the analysis of emerging information societies.

The article is based on an analysis of three sets of data: document material, interview data and material from an Internet online debate. The document material includes cabinet programmes between 1976-2003, national information society strategies and relevant offical documents of the Council of State, the Information Society Council and different ministries and agencies responsible for technology and communications policy in Finland. Furthermore, selected recent speeches of key decision-makers have been included in the document material. The interview data consists of two sets of interviews. For the purpose of this research, 10 personal interviews with representatives from state organisations responsible for information

2 There is a wide theoretical discussion on the concept of information society (e.g. Webster 2002, May 2002) and it is not the purpose of this article to go into that discussion. Information society is here used more as descriptive term referring to a society in which the development, use and application of information and communication technologies are increasingly prominent and related economic activities central (cf. Jaeger 2004).

3 Governance is thus not understood as limiting to 'new governance' forms referring to the proliferation of public-private partnerships, policy networks and divergent forms of selforganisation but rather as a broader concept referring to the co-ordination of social systems and the role the state in that process (see Pierre 2000). Thus defined governance is "as old as government" and the new forms present recent changes in governance (Pierre \& Peters 2000:18, cf. Knill 2004). 
society and ICT (the Science and Technology Policy Council, Ministry of Transport and Communications, Finnish Communications Authority, National Technology Agency of Finland), from relevant co-operation and lobbying organisations in the field of communications policy and information society (Finnish Federation for Communications and Teleinformatics FiCom, Finnish Information Society Development Centre Tieke) as well as from labour market organisations (Conferedation of Finnish Industries EK and the Central Organisation of Finnish Trade Unions SAK) were carried out. In addition to these interviews, an earlier broad interview data consisting of 17 interviews with decision-makers in Finnish technology policy has been used in the analysis. ${ }^{4}$ The third set of data consists of a material related to an online debate organised by the Government in February 2004 on the future of the Finnish information society. This material consists of 223 messages that were sent to the online discussion forum. The method of analysis has been based on a close reading of the documents, transcripted interviews and messages sent to the Internet discussion forum and it has been guided by the conceptual framework of modes of governance which is presented next.

\section{Modes of governance}

To analyse governance of Finnish information society policy, the paper applies a conceptual framework of modes of scientific and technological governance (Hagendijk and Irwin 2006, Hagendijk et al. 2005). The typology focuses on the roles and identities that are assigned to citizens in decision-making concerning scientific and technological development. It seeks to understand how the citizenscience/technology relationship can be organised in different situations and how the input of the public is being defined and taken into account in the policy process. The framework is based on the assumption that a distinction between political and public arenas is important in respect to public engagement and participation. The political arena is related to the formal system of public decisionmaking, political representation and political parties while the public arena is part of the civil society including mass media, civil organisations and engaged individuals. Both arenas affect the preconditions and opportunities for public engagement. Engagement also takes place in both arenas, although there may be a mismatch in the sense that some issues are relevant in the public arena but not in the political arena or vice versa. In this distinction, the public arena thus comes close to the Habermasian conception of the public sphere: it is seen as a discursive space allowing for citizens to deliberate and debate about their common affairs (Habermas 1996) which is conceptually different from the state and the official economy (Fraser 1992). The following typology - based on Hagendijk et al. (2005) - describes six different types of governance.

4 From some organisations several persons were interviewed. In these cases interviewees are differentiated by referring to them with letters A and B. 
In discretionary governance policy making takes place practically without any explicit interaction with the public. Decisions are carried out without much input from any groups outside the governing bodies. Such a mode of governance is based on implicit public trust which has long prevailed in issues related to science and technology. Thus, for science and technology policy, discretionary governance can be seen as 'basic mode' underlying many practices to larger extent than in most other societal domains where issues have normally been more politicized. This is particularly the case in Finland where there has been a broad consensus over the societal importance of science and technology over decades. Educational governance implies that there are emerging or manifest tensions between prevailing public policies and 'the public'. Lack of adequate information and knowledge is considered to be the cause for the disturbances. Educational governance is based on the Enlightenment conception of science-citizen relationship as experts play the dominant and active role while the public remains a passive receiver of information. Educational approaches are highly hegemonic as the distribution of critical resources is conceived in terms of haves and have-nots and negotiation and learning processes are strictly linear, from one of the parties to the other. Educational governance modes have often been related to the building up of welfare regimes and states which have been developed through strong state intervention and a topdown strategy.

Deliberative governance takes a very different stand on public engagement: it is non-hegemonic as it is based on the idea of equal access and carried out as an open-ended process where no actor has an advantage over others in terms of the expected outcomes at the beginning. The existence of a public sphere or arena of opinion formation and debate among citizens is crucial for the deliberative model and free deliberations are seen as the way to promote the legitimation of the decisions (Benhabib 1992:88). The deliberative model dissolves the demarcation between science/technology and the public, facilitates public participation and focuses on rational public debate as a means to achieve a socially viable consensus. In many countries, public concern related to the health risks and moral and ethical questions that new technological developments are presenting has indeed led to the call for for more participatory forms of governance. The idea is that citizens would be asked to help in assuring quality in decision-making by developing their own perspectives on the new technologies they confront in daily life. In general terms, such broader participation can be justified by political and strategic reasons (increasing accountability and stability of decisions), ethical considerations (citizens are the ultimate source of social values which are expressed in the decision-making) or knowledge-related arguments (the public possesses different kind of knowledge than decision-makers) (Sundqvist 2003). While deliberative governance pulls the process towards the public arena, corporatist governance tends to pull it away from the public arena. Corporatist mode of governance implies a closed process of deliberation and negotiation between the privileged stakeholder groups. It is normally highly hegemonic in terms of inclusion and exclusion of players and interests, as players have to be consulted and 'picked' by 
the state institutions in order to influence the process. The power structure essentially depends on which actors are included, and particularly to what degree the corporatist governance structure is inclusive towards civic interests and organisations such as NGOs.

Market governance refers to circumstances where the commercial and marketable aspects of science and technology are underlined in their societal role. In these cases, the value of science comes from the surplus value generated through its commercialisation and the contribution to the generation of wealth in society. In state politics, market governance is illustrated in terms of neo-liberal policies emphasizing results, customer orientation and competition. In market governance, public participation is mainly conceived through their role as customers and consumers in the market. It thus draws the process away from both the political and public arenas. In market governance, the public influences and assesses science and technology policy post hoc, after the completion of the innovation process. Agonistic governance, in turn, emerges if positions are strongly opposed, compromises are not easily found and conditions are not in favour of achieving a consensus through negotiation and debate. The agonistic mode is a protest against the dominant framing, usually based on discretionary, educational or corporatist governance, which excludes substantial influence by the public. Direct action in terms of boycotts and demonstrations for instance may then be characteristic. Conceptually agonistic model of democratic decision-making is often presented as critique towards the deliberative model which is seen as lacking the aspects of political power and conflicts (Mouffe 1999) and being culturally neutral (Young 1996). It pulls the process to the public arena and is anti-hegemonic as it questions the terms of the policy framework and conflicts are at its core. While agonistic forms of governance have been rarer in respect to new technologies in Finland than in many other European countries, environmental questions represent a very different experience as there have also been strong agonistic movements.

\section{Information society policy and modes of governance - mixing corporatist tradition, market forces and educational strategies}

In the following, the typology of modes of governance is applied to Finnish information society policy. As the typology is based on ideal types, identifying 'pure' types as such is difficult and overlaps and combinations of different types are common in practice. Here the core of the 'Finnish model' is interpreted in terms of a combination of corporatist, market and educational modes of governance.

\subsection{Restricted deliberations in the corporatist governance tradition}

Traditionally the relationship between government and society in public decision-making in Finland has been played out in terms of corporatist arrangements. Corporatist modes of action have been a characteristic feature of national 
politics since the 1960s when the dominant politico-administrative ideology emphasized the creation of a uniform network of welfare services and the settlement of conflicts between capital and labour through an integrated and centralized negotiation and contract arrangement. One of the main outcomes of corporatism has been the strengthening of consensual politics as the state has granted interest organisations permanent positions in the planning and decision-making system in certain policy domains. The 1980s has often been termed the golden age of consensual politics with high emphasis on consensus among the decision-makers in politics, business and interest organisations (Taivalsaari 1990). In the late 1990s and early 2000s, however, corporatist and consensual structures have been under pressure from changes related to globalisation. In several European countries, neoliberal policies have targeted at pulling down the collective labour market institutions and suppressing the influence of the labour unions (Ruostetsaari 2003:111). In Finland, however, corporatism seems to have coped rather well with the changes in the 1990s. The influence of the interest organisations has been extending to several policy sectors such as foreign, security and integration policies and the EU membership has brought them new institutionalised channels of influence (ibid. 114). Most recently, the corporatist system has been challenged by the relocation of industries to countries with low production costs. This has prompted a discussion of the so called German model: the increase of firms' local agreements with their employees to increase working hours without wage increases in order avoid the relocation of factories. The introduction of similar arrangements in Finland has been requested by representatives from industry, such as Nokia's former CEO Jorma Ollila, but these propositions have immediately been turned down by the labour unions. In their recent strategies, the labour unions, therefore, stress the importance of upholding the centralized, corporatist decision-making system also under the globalizing economic environment (SAK 2006). Yet, as employer organisations have recently taken a negative stand on centralized wage agreements, the future of this central corporatist element in Finnish politics is currently unclear.

Given this general corporatist structure, it is not surprising that state-led corporatist committees including representatives from industry, universities and the trade unions have been commonplace and increasingly significant in the concrete attempts to develop ICTs in Finland from the 1960s onwards. ${ }^{5}$ The Committee for Computer Policy, established in 1972 to govern the state computer procurement and the Advisory Board for Electronic Data Processing Industry, established in 1975 as a forum between public and private sectors, users and experts in the field were among the first state-led corporatist committees. Due to the generally high degree of labour unionization (nearly 80 per cent $)^{6}$, trade unions

5 In the 1950s it was mainly the scientific community which engaged in promoting research and development in ICT.

6 In this respect the ICT sector has been exceptional since the employees in the ICT sector have not generally been active to unionize. During the ICT boom the sector was unorganised and it 
have been strong players in these corporatist structures (e.g. Komiteanmietintö 1991). Under these circumstances, the trade union support for accelerating technological development has been central for the development of ICTs in Finland. Up until the late 1970s the trade unions had a critical stand on technological progress suspecting that it will substantially reduce jobs. After the influential Technology Committee (1979-80) argued that the effect on employment will not be negative, the labour union adopted a positive attitude on technological development in which technological progress is not considered to destroy jobs but rather as a means to achieve higher wages.

Already in the 1980s the labour union as a whole saw that this [technological development] is the opportunity through which jobs can be created in Finland, and that is what happened in the 1990s. The technological breakthrough, in particular in the telecommunication sector, has been the cornerstone of the success, but it has not happened on the expense of other industries. It is not that other industries have weakened, but telecommunication sector has raised along the existing industries. We regard technological progress in positive terms. (A representative of the Central Organisation of Finnish Trade Unions SAK.)

As a consequence of labour unions' change of attitude and its tighter integration to the political apparatus of the state, the corporatist system oriented more towards consensus while its aptitude for agonistic modes of governance diminished significantly. Operation of the corporatist negotiation system during the ICT boom in the late 1990s provides an example of its consensus-driven features: despite the booming economy the corporatist system led to an agreement which guaranteed only moderate rises in wages in all sectors, although productivity growth in ICT industry for instance was much higher and higher rises in wages would have been possible. The labour unions' consent on a moderate rise in wages was thus an important factor in enabling the success of ICT industry in Finland (cf. Ornston 2006).

Besides labour unions, high tech firms, and particularly Nokia, have been gaining increasing clout in corporatist governance structures. High-tech firms have strong representation in corporatist system, and Nokia, for example, has numerous representatives in the highest decision-making bodies. Nokia's representatives have been influential for instance in the work of the Science and Technology Policy Council which directs and coordinates science, technology and innovation policy in Finland. Also in more general terms, the success and growth of Nokia has made it dominant in the Finnish economy and very influential in Finnish society. The statements of its leaders on Finnish tax rates have been taken very seriously by governments and the question of whether Nokia will keep its headquarters in Finland has become an issue of national interest. This has prompted some to ask whether Nokia has become a 'state within a state' and too big for a small country like Finland (Cowell 2002).

was only when the new economy recession started in the early 2000 that the employees started to join unions. 


\subsection{From exclusive towards inclusive corporatism?}

In general terms, the Finnish corporatist governance system has tended to come close to the discretionary governance model as there have been relatively limited interactions with the public. The consensus-driven elements of the system have made it exclusive rather than inclusive in respect to influences that are 'external' to the system. Although civil society has long been active and well-organised (Siisiäinen 1999), non-governmental organisations are less integrated to policymaking in Finland than in other Nordic countries in general (Bouckaert et al. 2000: 15). Indeed, NGOs consider that their opportunities to take part in policy-making should be increased (Virtanen 2001:43). Also in respect to information society issues, the corporatist governance model has been exclusive, even though in the late 1990s and early 2000s there have been attempts towards increasing the integration of NGOs. ${ }^{7}$ The Information Society Council (2003-2007) and its predecessor the Information Society Advisory Board (1999-2003) are examples of a more inclusive approach. Headed by the Prime Minister, the council is the government's negotiative and advisory body in information society issues and has broad representation of ministers, high level civil servants, corporate directors, as well as several NGOs such as the Mannerheim League for Child Welfare, the Union for Rural Education, the Workers' Educational Association and the Finnish Consumer Association. ${ }^{8}$

Similarly, there has been a tendency towards an increasing integration of NGOs in the formulation process of national information society strategies. The first Finnish information society strategy was formulated in 1994-1995 in a closed process by a small working group consisting of representatives from the state administration (Ministry of Finance 1995). The strategy or draft versions were not circulated for comments. The outcome was a programme that emphasized economic and technological aspects and left social dimensions very much untouched (Pelkonen 2003). Due to the shortcomings of the first strategy a new strategy process was started soon after the completion of the first and a new strategy was published in 1998. The second strategy process was more interactive and not only top-down but also bottom-up approaches were introduced. NGOs were called to participate in the process and in total 53 NGOs took part in the strategy process (Sitra 1998). Public hearings or other participatory events were not organized. Yet, this programme, unlike the first one, never gained the status of an official governmental strategy. The latest strategy, issued in September 2006, was prepared by using future panels and workshops involving over 400 experts (Prime Minister's Office 2006), but direct public consultation was not used.

Although there are some signs of opening towards more inclusive forms of corporatism, the general model is still rather exclusive and shows only limited

Similar observations have been made in respect to biotechnology (Rask 2008).

8 Under the period 2007-2011 the work of the Information Society Council is continued by the Ubiquitous Information Society Advisory Board which is headed by the Minister of Communications. 
deliberative potential. Currently, the deliberative forms take place inside the established corporatist decision-making system and the deliberative processes are not brought into the public arena. Larger groups of the public or NGOs are thus not integrated into the deliberations. The collective nature of the corporatist structure also tends to exclude individual citizens from the processes. Firms, research institutions, state agencies, labour unions and ministries are the principal parties in the deliberative models inside the corporatist system while contacts to NGOs are generally weak. The role of NGOs is generally limited to commenting on proposals for new legislation and national strategies. According to the interviews, however, NGOs have been rather passive in participating, at least in relation to communications legislation:

They (rounds of comments) are indeed broad, there are normally all media companies, telecommunications companies, there are all the ministries, municipalities, NGOs as much as we are able to think of, and normally we ask for a statement from all of them. They (NGOs) are not very active; they do not aim at influencing things very much. (Representative A from the Ministry of Transport and Communications.)

There are views, however, that there may be a need for increasing interaction with the public in future. Representatives from the public administration responsible for ICT issues have indeed announced that direct public participation will be increased and citizen panels to form opinion on electric services has been taken up as a possible method for increasing participation (e.g. Council of State 2003). At the same time there are doubts among the authorities whether new kinds of participatory mechanisms would actually fit the Finnish system.

If you look at wireless local area networks, somebody can always follow the data transmission if you use your PC in a hot spot at the airport. When people become aware of these risks, it is possible that there will be more interaction [between authorities and the public] after that. But as there has not been any [problems], everything has gone very smoothly. (Representative A from the Ministry of Transport and Communications.)

I would actually regard it as a part of the Finnish culture and our way of doing things, and somehow it just is that these [participatory] forums do not fit our system very well (Representative B of the Ministry of Transport and Communications).

Currently, however, the strong corporatist system, together with growing market governance, does not leave very much space for public participation. One of the interviewees put it like this:

But how is their [citizens'] voice heard? The voice of industry, firms is heard, we have advisory boards, working groups where they are represented, but we don't have consumer associations in these bodies. - - But who speaks with the voice of the consumer? (Representative from the Finnish Communications Authority.)

The inclusion of the consumer perspective is problematic, but it seems evident that the integration of a broader citizen perspective to the corporatist structures is 
even more difficult. While networking and cooperation between different societal actors and sectors is often considered a central asset of the Finnish innovation system (e.g. Schienstock 2004:294-295, Castells and Himanen 2002:73-76), less attention has been paid to the underlying corporatist political culture that prevails in decision-making related to technological development and its implications for public engagement. Corporatist governance tends to strengthen consensual aspects and exclude critical and agonistic voices and broader public discussion.

\subsection{Telecommunications policy by market forces}

Although the building up period of the Finnish welfare state was characterized by a strong state penetration into economic activities (Alestalo 1991), the telecommunications sector has been different in this respect. The Finnish telecom sector is peculiar in the European scale in the sense that it has never been dominated by a state monopoly but there has always been competition among local telecom operators. Competition in telecommunications in Finland originates from the pre-independence era when Finland was part of Russia. In 1879 the Finnish Senate made a decision that - in order to avoid Russian intervention Finnish telephone activities must be left to the private sector (Steinbock 2000: 20-21). In most European countries telephone services were regarded as an exclusive right of state action which resulted in state monopolies. The Finnish decision resulted in economic competition: at its highest there have been over 800 Finnish telephone companies in the 1930s (ibid. 22).

Given the competitive basis in Finnish telecommunications, starting the liberalization of markets in the mid 1980s was easier in Finland than in many European countries. The start of deregulation and liberalisation however happened in the midst of the strong welfare state period with rigid state regulation. Compared to other European countries, Finland was early to adopt the strategy of market liberalisation. The main phases of liberalisation took place between 1987 and 1994 as competition in corporate networks and data transmission (1987), in data networks and GSM-networks (1990) and in local, long-distance and international telecommunications (1994) were liberalized. In practice, the liberalisation has meant that new actors have been able to enter the market without heavy license conditions. Also the Finnish broadband policy has been particularly market-oriented, and differs, for instance, fundamentally from the policy adopted in Sweden where the government facilitates the expansion of broadband infrastructure to the peripheral areas through state subsidies (Granholm 2003). Similarly, exposure limits to mobile phone radiation vary substantially among countries (World Health Organization 2006). In many countries the regulation is stricter than in Finland and authorities are more cautious concerning, for instance, childrens' use of mobile phones (see Ahtiainen 2007, Koistinen 2006).

Early liberalisation of the telecommunication market has been regarded as one of the success factors behind the 'Finnish miracle' in mobile communications (e.g. Häikiö 2001). The policy makers tend to term the Finnish approach as 'telecommunications policy by market forces' where state regulation is as minimal as 
possible (Pursiainen 2003:15) and the role of the state is limited to the creation of preconditions for firms to act in the markets. The policy is based on the belief that relying on competition and market liberalization also provides consumers with good services.

Why it is considered good is that it is the doctrine that currently dominates. So competition really produces efficiency which means benefits for customers and products and it promotes business development. (Representative of the Finnish Communications Authority.)

In the light regulatory framework the state's competences are increasingly limited and the role of the public is mainly played out in terms of consumer choices in the market place. The citizens are primarily regarded as consumers of ICT products and services.

It means in practice that, from the perspective of communications policy, it would be more descriptive to talk about an end-user who is actually a citizen who uses this equipment. And our objective is to make sure that these end users, citizens, have the best possible services. (Representative B of the Ministry of Transport and Communications.)

Bauman (1999:72-78) has argued that - in the passage to the late-modern era market pressure has superseded political institutions and legislation in creating the constraints confining individual choices, and the individual has been transformed from political citizen into market consumer. Citizens are thus increasingly expected to express their will through markets and less through politics and elections (Kantola 2003:208). Although consumer choices in the market may in some cases affect policies, primarily and more directly they have an impact on corporate strategies and actions. Moreover, actions and preferences of a single consumer are not influential as such, but gain importance only in aggregate, in relation to other consumers' actions and preferences. In this respect, market governance is sensitive to aggregate-level agonistic forms of governance such as boycotts and consumer protests for instance. Yet market governance is insensitive to the political process and draws the process away from the political arena. Thus the room for manoeuvre of national policies is in decline when market governance is applied. Mergers of national telecom operators into supranational coalitions provide one example of such situation.

Also the possibilities to influence through national policies are diminishing all the time when these supranational coalitions emerge. Telia-Sonera ${ }^{9}$ is still quite small but when a large European company will join the coalition, you can't do very much through the means of national telecommunications policy. If you think of broadband policy or regional equality or social equality or something like that, it is quite difficult to implement national measures in this situation or set any obligations to the operators. (Representative A of the Ministry of Transport and Communications.)

9 Telia-Sonera is a Swedish-Finnish telecom operator which was created when Swedish Telia and Finnish Sonera were merged in 2002. 
As the state and politics are thus losing power to the markets, the social dimension may become marginalized. This is reflected in the increase of social inequalities related to growing market orientation.

\subsection{Market governance and new exclusions}

In Finland the strengthening of market governance in telecommunication policy has also been part of a more profound state restructuration which has led to the rise of market-orientation and restriction of the welfare dimension (e.g. Alestalo 1993, Häyrinen-Alestalo et al. 2004, Julkunen 2001, Kantola 2002). In this development, the Finnish state has largely adopted policies of a competition state that prioritises competitiveness and innovations and may subordinate social issues to economic concerns (Pelkonen 2008). During the 1990s, social and health policies, for instance, underwent significant transformations which included the reduction of the level of social benefits (e.g. Riihelä et al. 2002). This change appeared to be permanent as social benefits have not been raised during the growth period (Kautto 2003:1). When analysing these changes, Anttonen and Sipilä (2000:275) have concluded that 'the shift from universal to marginal welfare policy has provided the citizens with decreasing rights, uncertainty over authorities' decisions, social exclusion, high administrative costs and new income traps'. At the same time, public investments in the promotion of the 'knowledge economy' have been substantially increased, in particular through massive public funding for research and development, raising the share of R\&D of GDP in Finland second highest in the world.

I have not seen a similar situation in any other country. When the additional public $R \& D$ funding programme was started [1996], at the same time about 20 billion [marks] were cut from the state budget. ${ }^{10}$ As somebody said a bit maliciously, the money was taken from the poor and invested in research, but that is in principle quite close to what actually happened. (Representative from the National Technology Agency Tekes.)

While giving room for markets and limiting the role of the state, market governance tends to challenge the old principles of the welfare state - such as equality - which are based on the idea of citizenship. Equality between social groups and regions has been one of the core ideas of the Finnish welfare state. As market governance is based on the functioning of the market mechanism and regards citizens primarily as consumers, the equality perspective tends to become marginalized. New exclusions and social conflicts are then more likely to occur and the emergence of agonistic forms of governance becomes more probable. Market governance has a tendency to marginalize some groups of citizens and in this respect it begins to resemble the discretionary governance model.

Growing inequality between social groups has indeed become an increasingly severe problem. While some of the most eager proponents of the 'Finnish model'

10 The additional R\&D funding programme was funded with money gained from the privatisation of state-owned companies. 20 billion marks correspond to 3.4 billion euros. 
consider that the Finnish welfare system survived the cutbacks during the recession of the early 1990s and thereafter 'fundamentally unchanged' (Castells and Himanen 2002:83-85), several recent studies show that inequality rose significantly during that period (Riihelä et al. 2007, 2005, 2002, Kautto 2003). Since 1994 there has been a clear increase in income differences: the rich have become richer and the poor increasingly poorer (Riihelä et al. 2005). One reason has been the reform of the tax system in the early 1990s which decreased the system's redistributive impacts and led to the growth of capital income and the decline in the average real disposable income of the continuously high number of unemployed households (Kautto 2003, Riihelä et al. 2005). Indeed, even the fast rise of the ICT cluster did not solve the problem of unemployment which has remained relatively high. Only during the last few years, unemployment rate has gone below the EU average (5,9 per cent in September 2008). Although unemployment has decreased since the recession years, women's unemployment has decreased slower than men's. Especially the long term unemployment has remained high and increased poverty making social exclusion a severe social problem in the country.

Regional inequality also increased dramatically during the 1990s, although the Finnish state has not embraced as a clear-cut strategy to directly prioritize urban growth regions as several other European countries have (Pelkonen 2005). Especially in the late 1990s the ICT-driven growth was related to regional polarization and increasing regional inequalities. Helsinki and Tampere regions in the south and Oulu in the north have been the fastest growth poles as the new ICT entrepreneurship has concentrated on these areas. Currently these three regions account for over 75 per cent of the total R\&D expenditure in the country (Statistics Finland 2007). In particular the growth of Nokia has increased regional income differences: the regions where Nokia mainly operates - Helsinki, Salo and Oulu correspond with regions where household incomes have been among the highest (Statistics Finland 2002). On the other hand, the most peripheral regions in the northern and eastern parts of the country are continuously losing population and lacking entrepreneurship. Currently Finland has the most pronounced regional polarisation among the Nordic countries, in particular in terms of differences in regional unemployment rates (Neubauer et al. 2007, 22-23). As a result, numerous municipalities are struggling to provide their inhabitants with high quality welfare services while the social problems in biggest cities have increased (e.g. Kasvio 2002). Furthermore, market governance also brings forward the problem of the digital divide as the market mechanism is incapable of bringing certain ICT services, such as broadband services, to the peripheral regions of the country. Growing inequalities, social exclusion, high unemployment and degradation of public services have therefore laid opportunities for the increase of agonistic forms of governance. During the recession years, major demonstrations against unemployment were indeed seen but since then they have been less common, mainly occurring when public services have been under threat. 


\subsection{Educational strategies and initiatives}

As the development of the Finnish information society has strengthened, the corporatist and market-oriented modes of governance have also started to link with educational forms of governance. Uotinen (2003) has argued that the policy rhetoric on the Finnish information society has been deterministic, presenting the information society as an inevitable phenomenon, and universalistic, neglecting all societal and regional differences, as well as differences between people's local circumstances. Hence, in the official information society rhetoric, very little space is left for alternative understandings and interpretations of the information society such as people who, for instance, are reluctant to new technologies and do not want to use information technology (e.g. Ministry of Finance 1995, Sitra 1998).

Above all, however, the Finnish information society rhetoric, as put forward in the national information society strategies, is based on educational governance in which the citizens are educated to understand the benefits, but also challenges, brought by the 'new' society. The need to convince the public of the benefits of the information society project in this way indicates a potential lack of public support.

For citizens, the most important thing is to be able to feel that they benefit from the information society development. Through benefits, the ability to take up new electronic services or devices grows. As a consequence, also enthusiasm for continuous change, characteristic to the information society, becomes greater (Ministry of Transport and Communications 2002:11).

The information society is presented as an educational project and the primary message of the programmes tends to be that the information society is a society of lifelong learning. The new society provides a lot of new possibilities, but taking advantage of these possibilities requires new skills in all spheres of life and these new skills have to be learned. This deterministic perspective has been well put forward by former Minister of Transport and Communications Kimmo Sasi (2002), when he stated that in educational policy, the guideline is that every citizen must understand the value of the information society and possess the basic knowledge and skills of the citizen of the information society.

Citizens are expected to be active, educate themselves continuously, take increasing responsibility of their lives and adapt to changes. The emphasis on 'active citizenship' also implies a distancing from the ideology of the welfare state. In the first national information society strategy, this is made explicitly by criticizing the welfare state of being paternalistic and too protective (Ministry of Finance 1995:39). While citizens are provided with increasing responsibility, in the strategies' rhetoric they mainly gain power in the role of consumers, which again refers to the rise of market governance.

Yet, educational aspects of governance extend beyond the rhetoric of information society strategies to actual events and measures. A recent attempt to foster public debate on the use of ICT provides a good example and it can also be seen as a case in which deliberative and educational modes of governance merge. 
Encouraging public debate was regarded important (Harjuhahto-Madetoja 2004) and one reason for this is that public discussion on issues related to science and technology is exiguous in Finland compared to many European countries. This holds to the developments related to new biotechnology (Snell 2002), as well as to issues related to the social impacts and application of information and communication technologies. The public discussion and media coverage in ICTs is focused on economic issues and firm performance while social dimensions or technological risks are rather scantly communicated. Mobile phone safety for instance has been very weakly discussed in the public arena although there are NGOs that consider radiation as a health risk and strongly oppose the current economy and marketbased framing of technological issues. In this respect the dominant economic significance of the ICT sector in the country may hold back the discussion.

In context of the launch of the governmental information society programme, a new approach to public debate was experimented by organising an online discussion entitled 'The Information Society in the Near Future'. ${ }^{11}$ In general, the debate can be seen as an attempt to draw the scarcely discussed topic to the public arena and it brought out a number of risks and concerns related to new information and communication technologies. In this respect, access to fast broadband connection with reasonable price in all parts of the country was considered of central importance. This highlights the role of the state as well as the importance of regional equality. Further concerns were related to data security, exclusion from the information socity and the availibity of public services in the Internet (see also Government Information Society Programme 2004).

Although it seems that the original idea was to activate public discussion and get inputs for policy formuation, the way the debate was organised and implemented shows tendencies of educational rather than deliberative forms of governance. First, in the opening of the discussion, citizens were asked to answer certain questions by the information society programme director (HarjuhahtoMadetoja 2004). In this respect, the opening of the debate was organised around top down -approach rather than from an even-handed perspective. Naturally, however, a lot of issues were discussed in the forum that were not directly asked in the first place. Secondly, no clear indications were given whether the debate was to have an actual impact on policies. In the opening comment of the discussion, the information society programme director stated only that the citizens' comments 'will be helpful in evaluating the information society programme and in developing electronic services'. Thirdly and most importantly, representatives of the state administration did not take part in the debate, but citizens were left to discuss on their own. The debate was not a debate between citizens and the administration but among citizens and in this respect it does not reflect a deliberative process where all parties should take part in the process. During the

11 The debate was organised in February 2004 and during 29 days 223 messages were sent to the forum by over 100 persons. 
debate, several persons called for the representatives of the administration to take part in the debate. For instance:

Public administration and decision-making should in general terms be public and it should be possible to track the decisions afterwards. When I'm suggesting that decision-makers should themselves consider these questions, I'm thinking that they should discuss about these issues here [in this forum] with the citizens. In this way, they would be adviced by the citizens in decision-making, as it should be in representative democracy (message 150).

It was thus considered that only by integrating civil servants or decisionmakers into the dicussion the debate would have an impact. Enhanced public discussion was urged, not only in respect to the information society, but more generally also.

\section{The 'Finnish Model' reconsidered}

Tensions between different modes of governance tend to emerge along with the strengthening of the information society in Finland. The corporatist governance model based on the welfare state tradition is increasingly challenged by market governance which tends to question the equality approach and bring up new divides and exclusions. During the 1990s, social inequality grew significantly in Finland, and in this respect, it can be argued that the equality side of the so-called Finnish model - as put forwards by Manuel Castells and Pekka Himanen - is actually an illusion (cf. Patomäki 2003). The shift towards market governance limits state's regulative capacities and highlight the public mainly as consumers, not as citizens who have the right to influence the political process.

At the same time deliberative governance ideas emerge to question the closed structures of corporatism and call for greater openness and engagement. Alongside strong pressures to improve competitiveness, public engagement in scientific and technological development and related decision-making has become a crucial issue in both EU policies as well as in national politics in many member states (as for instance Denmark, the Netherlands and the UK). In Finland, the political apparatus mainly remains, however, tied to the more traditional Enlightenment model. Although the corporatist governance tradition seems to be moving towards more inclusive models, it still remains rather exclusive vis-à-vis civic organisations, and particularly, individual citizens.

Currently the limited deliberative forms of governance take place inside the corporatist system. There is thus restricted space for the integration of the citizen perspective and simultaneously there is uncertainty and suspicion in the public administration whether more deliberative models would work in Finland. The lack of deliberative forms relates also to the more general Finnish conception of democracy. In Finland, the representative forms of democracy have traditionally been more emphasized. Finnish political culture does not encompass such emphasis on political participation and individual influences. On the contrary, 
there is a strong belief in authorities and experts and the culture does not encourage challenging the dominant views. At the same time, the educational mode of governance seems to dominate the rhetoric in the national information society strategies, thus leaving very limited space for alternative understandings and interpretations of the information society. Hence, from the governance perspective, the core of the Finnish 'model' is one which combines strong market orientation with relatively exclusive corporatist tradition. At the same time, the insignificance of both deliberative and agonistic forms of governance is characteristic to the Finnish experience.

\section{Acknowledgements}

I wish to thank Marja Häyrinen-Alestalo, Peter Healey, Eeva Luhtakallio, Mika Nieminen and Juha Tuunainen for valuable comments on earlier versions of this article. The study was originally carried out in the context of the EU research network Science, Technology and Governance in Europe (STAGE).

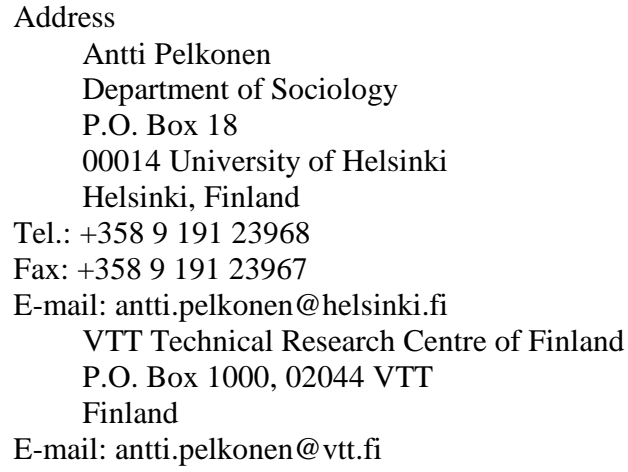

\section{References}

Ahtiainen, Ilkka (2007) "Moni maa Suomea huolestuneempi lasten kännykän käytön riskeistä". [Many countries are more concerned than Finland about childrens' use of mobile phones.] Helsingin Sanomat 31.3.2007.

Alestalo, Marja (1993) "The rise of neo-liberalism in Finland: from the politics of equal opportunity to the search for scientific excellence". Science studies 6, 2, 35-47.

Alestalo, Marja (1991) Science and the politico-economic system. Helsinki: VAPK-Publishing.

Anttonen, Anneli and Jorma Sipilä (2000) Suomalaista sosiaalipolitiikkaa. [Finnish social policy.] Tampere: Vastapaino.

Bauman, Zygmunt (1999) In search of politics. Cambridge: Polity Press.

Borg, Sari (2004) Kansalainen Suomessa. [Citizen in Finland] Helsinki: Oikeusmininsteriö.

Bouckaert, Geert, Derry Ormond, and Guy Peters (2000) A potential governance agenda for Finland. Helsinki: Ministry of Finance. 
Benhabib, Seyla (1992) "Models of public space: Hannah Arendt, the liberal tradition, and Jürgen Habermas”. In Habermas and the public sphere, 73-98. Craig Calhoun, ed. Cambridge: MIT Press.

Benner, Mats (2003) "The Scandinavian challenge: the future of advanced welfare states in the knowledge economy". Acta Sociologica 46, 2, 132-149.

Cabinet Programmes in Finland 1976-2003.

Castells, Manuel and Pekka Himanen (2002) The information society and the welfare state. The Finnish model. Oxford: Oxford University Press.

Council of State (2005) Hallituksen politiikkaohjelmat - kansalaisvaikuttaminen. [Government policy programmes - citizen participation.] Consulted December 2005 http://www.vn.fi

Council of State (2003) Tietoyhteiskuntaohjelman toteutussuunnitelma. [Implementation plan of the information society programme.] Consulted April 2007 http://www.hare.vn.fi

Cowell, A. (2002) "Not Finland anymore? More like Nokialand". The New York Times, February 6, 2002.

Fraser, Nancy (1992) "Rethinking the public sphere: a contribution to the critique of actually existing democracy". In Habermas and the public sphere, 109-142. C. Calhoun, ed. Cambridge: MIT Press.

Government Information Society Programme (2004) "Lähitulevaisuuden tietoyhteiskunta. Kooste keskustelun pääteemoista". [Information society in the near future. Summary of the main themes of the discussion.] Consulted April 2007 http://www.tietoyhteiskuntaohjelma.fi

Granholm, A. (2003) Broadband in rural Sweden. Consulted August 2004 http://www. seutuverkot.net

Habermas, Jürgen (1996) "Three normative models of democracy". In Democracy and difference 21-30. S. Benhabib, ed. Princeton: Princeton University Press.

Hagendijk, Rob, Peter Healey, Maja Horst, and Alan Irwin (2005) Science, technology and governance in Europe: challenges of public engagement. STAGE Final Report.

Hagendijk, Rob and Alan Irwin (2006) "Public deliberation and governance: engaging with science and technology in contemporary Europe". Minerva 44, 2, 167-184.

Harjuhahto-Madetoja, Katrina (2004) "Keskustelunavaus". [Opening of the discussion.] Opening statement of the online discussion on the Finnish information society. Consulted November 2005 www.otakantaa.fi

Heiskala, Risto (2006) "Kansainvälisen toimintaympäristön muutos ja Suomen yhteiskunnallinen murros". [Transformation of the international operational environment and societal change in Finland.] In Uusi jako. Miten Suomesta tuli kilpailukyky-yhteiskunta?, 14-42. [New divide. How Finland became a competitiveness society?] Risto Heiskala and Eeva Luhtakallio, eds. Helsinki: Gaudeamus.

Himanen, Pekka and Manuel Castells (2004) "Piilaakson ja Suomen tietoyhteiskuntamallit". [Information society models of Silicon Valley and Finland.] In Globaali tietoyhteiskunta. Kehityssuuntia Piilaaksosta Singaporeen, 35-52. [The global information society. Development paths from Silicon Valley to Singapore.] Pekka Himanen, ed. Helsinki: Tekes.

Huovinen, Susanna (2006) "Viestintäpoliittinen katsaus". [Review on communications policy.] Minister of Transport and Communications Susanna Huovinen's speech at Viestintäfoorumi, 18.1.2006.

Häikiö, Martti (2001) Nokia Oyj:n historia. [History of Nokia.] Helsinki: Edita.

Häyrinen-Alestalo, Marja, Antti Pelkonen, and Karoliina Snell (2004) New Technologies Challenging Old Structures of Governance. (STAGE Discussion Paper, 7.) Consulted April 2007: http://www.stage-research.net

Information Society Council (2006) Tulevaisuuden elinvoimainen Suomi. [The vibrant Finland of the future.] Helsinki: Valtioneuvoston kanslia.

Jaeger, Birgit (2004) "Trapped in the digital divide? Old people in the information society". Science Studies 17, 1, 5-22.

Julkunen, Raija (2001) Suunnanmuutos. 1990-luvun sosiaalipoliittinen reformi Suomessa. [Change of direction. Social policy reform of the 1990s.] Tampere: Vastapaino. 
Kantola, Anu (2003) "Loyalties in flux. The changing politics of citizenship". European Journal of Cultural Studies 6, 2, 203-217.

Kantola, Anu (2002) Markkinakuri ja managerivalta: poliittinen hallinta Suomen 1990-luvun talouskriisissä. [Market control and managerial power: political governance in economic crisis in the 1990s.] Helsinki: Loki-kirjat.

Kasvio, Antti (2002) "Tietoyhteiskunta ja yhteiskunnalliset jaot". [Information society and societal divides.] In Yhteiskunnalliset jaot. 1990-luvun perintö?, 99-115. [Societal divides. A heritage of the 1990s?] Timo Piirainen and Juho Saari eds. Helsinki: Gaudeamus.

Kautto, Mikko (2003) "Welfare in Finland in the 1990s". Scandinavian Journal of Public Health 31, $1,1-4$.

Knill, Christoph (2004) "Modes of governance and their evaluation". Trames 8, 4, 352-371.

Koistinen, Olavi (2006) "Kännykkä on vaaraton, vai onko?" [The mobile phone is not dangerous, or is it?] Helsingin Sanomat 1.11.2006.

Komiteanmietintö (1991): Tietotekniikan kehitys yhteiskunnan toimivuuden edistäjänä: tietotekniikan neuvottelukunta 1989-91. [The development of information technology as a promoter of the functioning of the society: Information technology advisory board 1989-91.] Helsinki: Valtion painatuskeskus.

May, Christopher (2002) The information society. a sceptical view. Cambridge: Polity Press.

Ministry of Finance (1995) Suomi tietoyhteiskunnaksi. Helsinki: Valtiovarainministeriö.

Ministry of Transport and Communications (2002) Kuinka Suomesta tehdään kilpailukykyinen tietoyhteiskunta? Suuntana hyödyntäminen. [How Finland becomes a competitive information society? Towards utilisation.] Helsinki: Ministry of Transport and Communications.

Mouffe, Chantal (1999) "Deliberative democracy or agonistic pluralism?" Social Research 66, 3, $745-758$.

Neubauer, Jörg, Alexandre Dubois, Thomas Hanell, Kaisa Lähteenmäki-Smith, Katarina Pettersson, Johanna Roto and Jon Moxnes Steineke (2007) Regional Development in the Nordic Countries 2007. Stockholm: Nordregio.

OECD (2005) Employment outlook 2005. Paris: OECD.

Ornston, Darius (2006) "Reorganising adjustment: Finland's emergence as a high technology leader". West European Politics 29, 4, 784-801.

Patomäki, Heikki (2003) "An optical illusion: the Finnish model for the information age". Theory, Culture and Society 20, 3, 139-145.

Pelkonen, Antti (2008) The Finnish Competition State and Entrepreneurial Policies in the Helsinki Region. Research Reports No. 254. University of Helsinki: Department of Sociology.

Pelkonen, Antti (2005) "State restructuring, urban competitiveness policies and technopole building in Finland - a critical view on the glocal state thesis". European Planning Studies 13, 5, 685706.

Pelkonen, Antti (2003) "Tieto- ja viestintäteknologia teknologiavetoisen yhteiskunnan rakentajana ja yhteiskuntapolitiikan välineenä". [The political objectives of information and communication technologies - Towards a technology-driven society.] Politiikka 45, 1, 50-61.

Pierre, Jon (2000) "Introduction: understanding governance". In Debating governance, 1-12. Jon Pierre, ed. Oxford: Oxford University Press.

Pierre, Jon and B.Guy Peters (2000) Governance, politics and the state. London: MacMillan.

Prime Minister's Office (2006) A renewing, human-centric and competitive Finland. The national knowledge society strategy 2007-2015. Helsinki: Prime Minister's Office.

Pursiainen, Harri (2003) "Finnish telecom policy is removing obstacles and encouraging the markets". In ICT Cluster Finland Review, 14-15, Helsinki: Tieke.

Rask, Mikko (2008) Expansion of expertise in the governance of science and technology. National Consumer Research Centre: Helsinki.

Riihelä, Marja, Risto Sullströn and Matti Tuomala (2007) Economic Poverty in Finland 1971-2004. Tampere Economic Working Papers Net Series. Consulted May 2007 http://tampub.uta.fi.

Riihelä, Marja, Risto Sullström, and Matti Tuomala (2005) "Kuponginleikkaajan paluu: ylimmät tulot ja niiden verotus". [Highest income and taxation.] Talous ja yhteiskunta 1/2005, 14-20. 
Riihelä, Marja, Risto Sullströn, Ilpo Suoniemi, and Matti Tuomala (2002) Recent trends in income inequality in Finland. Helsinki: Labour Institute for Economic Reseach.

Ruostetsaari, Ilkka (2003) Valta muutoksessa. [Transformation of power.] Vantaa: WSOY.

Saari, Juho, ed. (2006) Suomen malli - Murroksesta menestykseen. [The Finnish Model - From radical change to prosperity.] Helsinki: Yliopistopaino.

SAK (2006) Muutoksen suunta - osaava ja oikeudenmukainen Suomi. [Direction of change competent and fair Finland.] Helsinki: Central Organisation of Finnish Trade Unions.

Sasi, Kimmo (2002) "Suomen menestystekijät tietoyhteiskuntatyöpajan suositusten valossa". [The success factors of Finland in the light of the recommendations from the information society workshop.] Speech of the Minister for Transport and Communications. Communications Forum, Helsinki, 20.11.2002.

Schienstock, Gerd (2004) "The Finnish model of the knowledge economy". In Embracing the knowledge economy. The dynamic transformation of the Finnish innovation system, 287-314. Gerd Schienstock, ed. Cheltenham: Edward Elgar.

Siisiäinen, Martti (1999) "Voluntary associations and social capital in Finland". In Social capital and european democracy, 120-143. Jan Van Deth, Marco Maraffi, Kenneth Newton, and Paul Whiteley, eds. London: Routledge.

Sitra (1998) Quality of Life, Knowledge and Competetitiveness: Premises and Objectives for the Strategic Development of the Finnish Information Society. Helsinki: Sitra.

Snell, Karoliina (2002) "Biotekniikkapolitiikan kansalaiskuva: kansalaiset, kuluttajat ja ihmiset Suomessa ja Euroopan Unionissa". [Image of the citizen in biotechnology policy: citizens, consumers and human beings in Finland and in the European Union.] Sosiologia 39, 4, 285295.

Statistics Finland (2007) "Research and Development Statistics". Consulted May 2007 http://www.stat.fi.

Statistics Finland (2002) Kotitalouksien aluetilit 1995-2000. Helsinki: Tilastokeskus.

Steinbock, Dan (2000) Finland's wireless valley: from industrial policies toward cluster strategies. Helsinki: Ministry of Transport and Communications.

Sundqvist, Göran (2003) Constrained deliberation: public involvement in Swedish nuclear waste management. Swedish case study for STAGE. Unpublished.

Taivalsaari, Eero (1990) Konsensus. Johdatus Suomen 1980-luvun historiaan. [Consensus. An introduction to the Finnish history in the 1980s.] Juva: WSOY.

Uotinen, Johanna (2003) "Involvement in (the information) society - The Joensuu Community Resource Centre Netcafé". New Media and Society 5, 3, 335-356.

Young, Iris Marion. (1996) "Communication and the other: beyond deliberative democracy". In Democracy and Difference, 120-136. Seyla Benhabib, ed. Princeton: Princeton University Press.

Webster, Frank (2002) Theories of the information society. London: Routledge.

Virtanen, Petri (2001) Karavaani kulkee ja koirat haukkuvat: kansalaisjärjestöjen osallistuminen yhteiskunnalliseen päätöksentekoon. [The participation of non-governmental organisations in societal decision-making.] Helsinki: Valtiovarainministeriö.

World Health Organization (2006) Framework for developing health-based EMF standards. Switzerland: World Health Organization. 